\title{
Effect of Pyridoxine Deficiency on Nucleic Acid Metabolism in the Rat
}

\author{
BY ANTHONY C. TRAKATELLIS AND A. E. AXELROD \\ Biochemistry Department, University of Pittsburgh School of Medicine, Pittsburgh, Pa., U.S.A.
}

(Received 22 May 1964)

\begin{abstract}
1. The nucleic acid metabolism in the pyridoxine-deficient rat has been investigated through studies on the incorporation of radioactivity from various isotopically labelled compounds into liver and spleen DNA and RNA. 2. In pyridoxine deficiency, the incorporation of radioactivity from sodium $\left[{ }^{14} \mathrm{C}\right]$ formate was apparently increased. The magnitude of this effect on incorporation into liver RNA and DNA and spleen RNA was approximately the same. The incorporation into spleen DNA was enhanced to a much greater degree. Administration of pyridoxine $24 \mathrm{hr}$. before the rats were killed reversed the changes in incorporation of radioactivity from $\left[{ }^{14} \mathrm{C}\right]$ formate. 3 . In pyridoxine deficiency, the incorporation of radioactivity from $\mathrm{DL}-\left[3-{ }^{14} \mathrm{C}\right]$ serine, $\left[8-{ }^{14} \mathrm{C}\right]$ adenine, $\left[\mathrm{Me}-{ }^{3} \mathrm{H}\right]$ thymidine and $\left[{ }^{2-14} \mathrm{C}\right]$ deoxyuridine was decreased. The incorporation of radioactivity from $\mathrm{L}-\left[\mathrm{Me}-{ }^{14} \mathrm{C}\right]$ methionine was not affected. No noteworthy differences in the effect of pyridoxine deficiency on the incorporation of radioactivity from $\mathrm{DL}-\left[3-{ }^{14} \mathrm{C}\right]$ serine into DNA and RNA were observed, whereas the effect of the deficiency on the incorporation of radioactivity from $\left[8-{ }^{14} \mathrm{C}\right]$ adenine into spleen DNA was somewhat greater than that into spleen RNA. Administration of pyridoxine $24 \mathrm{hr}$. before the rats were killed reversed the changes in incorporation of radioactivity from [3-14 C]serine and [8-14 C]adenine. 4. The adverse effects of pyridoxine deficiency on the biosynthesis of nucleic acids and cell multiplication are discussed in relation to the role of pyridoxal phosphate in the production of $\mathrm{C}_{1}$ units via the serine-hydroxymethylase reaction.
\end{abstract}

The profound effects of pyridoxine deficiency on cellular growth, i.e. production of lymphopenia (Weir \& Mueller, 1951), impairment of rate and quality of wound healing (Bosse \& Axelrod, 1948), inhibition of viral replication (Leftwich \& Mirick, 1949) and tumour growth (Bischoff, Ingraham \& Rupp, 1943; Miller, Baumann \& Rusch, 1945; Littman, Taguchi \& Shimizu, 1963), suggest a possible role for this vitamin in nucleic acid metabolism. It has been established that pyridoxal phosphate is involved in the production of 'active formaldehyde' via the glycine-serine interconversion. 'Active formaldehyde' participates in the biosynthesis of purine bases and of thymidine from deoxyuridine 5' -phosphate (Greenberg, 1961, 1963; Buchanan, 1960; Crosbie, 1960). These related observations stimulated the present investigation of nucleic acid metabolism in the pyridoxinedeficient rat. A preliminary report of part of this work has appeared (Trakatellis, Axelrod \& Montjar, 1964).

\section{MATERIALS AND METHODS}

Animals and diets. Male weanling albino rats of the Holtzman strain were used. The care of the animals, the composition of the control and pyridoxine-deficient diets and the treatment of inanition controls were as described by Trakatellis \& Axelrod (1964). The inanition controls received daily an amount of basal diet equal to that consumed by a pyridoxine-deficient partner. All other animals were fed ad libitum. The food intake of pyridoxine-deficient animals receiving pyridoxine $24 \mathrm{hr}$. before being killed was limited during this period of pyridoxine administration. Solutions of pyridoxine $(5 \mathrm{mg} . / \mathrm{ml}$.) and of the pyridoxine antagonist, deoxypyridoxine ( $2 \mathrm{mg} . / \mathrm{ml}$.), were prepared in $0.9 \% \mathrm{NaCl}$ and adjusted to $\mathrm{pH} 7.2$ for intraperitoneal injection.

Preparation and counting of nuclei. Nuclei, prepared by the procedure of Fischer, Holbrook \& Irvin (1963), were resuspended in $0.25 \mathrm{M}$-sucrose and counted in a Neubauer haemocytometer after dilution in $3 \%(w / v)$ acetic acid.

Separation of $R N A, D N A$ and protein. The methods of Schneider (1957) were used. Liver and spleen were quickly excised from killed rats, washed in ice-cold 0.25 M-sucrose and weighed after being blotted on filter paper and a $10 \%$ $(w / v)$ homogenate was prepared in ice-cold $0.25 \mathrm{M}$-sucrose with a hand homogenizer. Proteins and nucleic acids were precipitated with 2 vol. of ice-cold $10 \%(w / v)$ trichloroacetic acid, washed with 1 vol. of ice-cold $10 \%$ trichloroacetic acid and then extracted twice with ethanol at room temperature and once with ethanol-ether mixture $(3: 1, \nabla / v)$ at $60^{\circ}$. The precipitate was suspended in $2 \mathrm{ml}$. of $\mathrm{N}-\mathrm{KOH}$ and incubated for $20 \mathrm{hr}$. at $37^{\circ}$. DNA and proteins were precipitated by the addition of $0.4 \mathrm{ml}$. of $6 \mathrm{~N}-\mathrm{HCl}$ and $2 \mathrm{ml}$. of $5 \%(w / v)$ trichloroacetic acid and removed by centrifuga- 
tion from the supernatant RNA digest. Finally, DNA was separated from proteins by extraction with $5 \%$ trichloroacetic acid at $90^{\circ}$ with occasional stirring. Proteins were removed by centrifugation. In the incorporation studies, we compared recovery of total radioactivity of RNA extracted with the cold-phenol method (Trakatellis, Axelrod, Montjar \& Lamy, 1964) with that obtained by the procedure described above. Yields were very similar by both methods. Since protein contamination of RNA extracted by the coldphenol method is minimal, we concluded that any contamination of RNA by acid-soluble peptides in the present procedure is not significant.

Analyses. Proteins were determined by the method of Lowry, Rosebrough, Farr \& Randall (1951), DNA by the diphenylamine reaction according to the method of Burton (1956), and RNA by the orcinol reaction (Schneider, 1957).

Incorporation studies. Sodium $\left[{ }^{14} \mathrm{C}\right]$ formate (specific activity $1.00 \mathrm{mc} / \mathrm{m}-\mathrm{mole}), \mathrm{DL}-\left[3-{ }^{14} \mathrm{C}\right]$ serine (specific activity $2.56 \mathrm{mc} / \mathrm{m}$-mole), $[8-14 \mathrm{C}]$ adenine (specific activity $3.24 \mathrm{mc} /$ $\mathrm{m}$-mole), $\mathrm{L}-\left[\mathrm{Me}-{ }^{14} \mathrm{C}\right]$ methionine (specific activity $6.23 \mathrm{mc} /$ $\mathrm{m}$-mole), $\left[2-{ }^{14} \mathrm{C}\right]$ deoxyuridine (specific activity $32.4 \mathrm{mc} /$ $\mathrm{m}$-mole) and $\left[\mathrm{Me}^{3} \mathrm{H}\right]$ thymidine (specific activity $6.7 \mathrm{c} /$ m-mole), was obtained from the New England Nuclear Corp. Iso-osmotic solutions of these compounds were prepared and adjusted to $\mathrm{pH} 7 \cdot 0$. After 7-9 weeks each rat, except those injected with thymidine, received an intraperitoneal injection of $5 \mu \mathrm{c}$ of the described labelled compound $/ 100 \mathrm{~g}$. body wt. and was decapitated $4 \mathrm{hr}$. later.
$\left[M e^{3} \mathrm{H}\right]$ Thymidine was injected intraperitoneally at $10 \mu \mathrm{c} / 100 \mathrm{~g}$. body wt. and the animals were killed 24 or $66 \mathrm{hr}$. later. DNA and RNA samples were prepared from liver and spleen as described above, portions taken for chemical analysis, and the samples dried completely in a vacuum oven at $90^{\circ}$. DNA was dissolved in $1 \mathrm{ml}$. of $1 \mathrm{M}$ Hyamine 10-X hydroxide [a solution of $p$-(di-isobutylcresoxyethoxyethyl)dimethylbenzylammonium hydroxide in methanol purchased from Packard Instrument Co., La Grange, Ill., U.S.A.] at room temperature. After $30 \mathrm{~min}$. $9 \mathrm{ml}$. of a $0.5 \%(\mathrm{w} / \mathrm{v})$ solution of 2,5-diphenyloxazole in toluene (Packard Instrument Co.) was added and radioactivity was measured in a Packard Tri-Carb liquid-scintillation spectrometer. 1 M-Hyamine 10-X hydroxide (2 ml.) was added to the RNA sample at room temperature, the whole stirred with a glass rod, and after $1 \mathrm{hr}$. centrifuged to separate the salts. The salts, consisting mainly of $\mathrm{KCl}$, were washed twice with $1 \mathrm{ml}$. portions of $1 \mathrm{M}-\mathrm{Hy}$ amine $10-\mathrm{X}$ hydroxide. Negligible amounts of radioactivity were present in the final salt precipitate. A portion (1 ml.) of the combined Hyamine extracts was diluted with $9 \mathrm{ml}$. of a $0.5 \%$ solution of 2,5-diphenyloxazole in toluene and radioactivity measured as described. DNA and RNA samples prepared as above from animals that had not received any labelled substance served as blanks. Counting efficiency was approx. $54 \%$ for ${ }^{14} \mathrm{C}$ and $17 \cdot 7 \%$ for ${ }^{3} \mathrm{H}$. Maximal deviation between duplicate samples above 100 counts/min. was less than $10 \%$ of the mean, and that above 1000 counts/min. was less than $5 \%$ of the mean.

\section{Table 1. Effect of pyridoxine deficiency on spleen and liver $D N A$}

Experimental details are presented in the text. Mean values \pm S.D. are given. Eleven animals were used per group.

\begin{tabular}{|c|c|c|c|c|c|c|c|}
\hline \multirow[b]{2}{*}{ Group } & \multirow[b]{2}{*}{$\begin{array}{l}\text { Weight } \\
\text { (g.) }\end{array}$} & \multicolumn{3}{|c|}{ Spleen } & \multicolumn{3}{|c|}{ Liver } \\
\hline & & $\begin{array}{c}10^{-6} \times \\
\text { Nuclei/mg. }\end{array}$ & $\begin{array}{c}\text { DNA/mg. } \\
(\mu \mathrm{g} .) \dagger\end{array}$ & $\begin{array}{c}\text { DNA/nucleus } \\
(\mu \mu \mathrm{g} .)\end{array}$ & $\begin{array}{c}10^{-6} \times \\
\text { Nuclei/mg. }\end{array}$ & $\begin{array}{l}\text { DNA/mg. } \\
(\mu \mathrm{g} .) \ddagger\end{array}$ & $\begin{array}{c}\text { DNA/nucleus } \\
(\mu \mu \mathrm{g} .)\end{array}$ \\
\hline atrol & $187 \pm 6$ & $1 \cdot 76$ & $17 \cdot 2 \pm 0 \cdot 83$ & $9 \cdot 8 \pm 1 \cdot 1$ & $0 \cdot 21$ & $2 \cdot 35 \pm 0 \cdot 45$ & $11 \cdot 2 \pm 0.9$ \\
\hline nition control & $86 \pm 4$ & $1 \cdot 66$ & $16 \cdot 6 \pm 0 \cdot 72$ & $10.0 \pm 0.9$ & $0 \cdot 29$ & $2 \cdot 50 \pm 0.48$ & $8 \cdot 6 \pm 1 \cdot 4$ \\
\hline ridoxine-deficient* & $84 \pm 3$ & 1.53 & $14 \cdot 8 \pm 0.64$ & $9 \cdot 7 \pm 1 \cdot 2$ & $0 \cdot 22$ & $2 \cdot 28 \pm 0 \cdot 36$ & $10 \cdot 4 \pm 1 \cdot 0$ \\
\hline idoxine-deficient & $81 \pm 4$ & $1 \cdot 20$ & $12.6 \pm 0.54$ & $10 \cdot 5 \pm 0.8$ & $0 \cdot 19$ & $1.98 \pm 0.31$ & $10.4 \pm 0.9$ \\
\hline
\end{tabular}

* Animals received $5 \mathrm{mg}$. of pyridoxine intraperitoneally $24 \mathrm{hr}$. before being killed.

$\dagger P$ value for probability of difference between the mean values of the pyridoxine-deficient group and the remaining groups as derived from the $t$ test is $<0.001$.

$\ddagger$ Differences between mean values are not significant by the $t$ test.

Table 2. Effect of pyridoxine deficiency on spleen and liver $R N A$

Experimental details are presented in the text. Mean values \pm s.D. are given. Fourteen animals were used per group.

\begin{tabular}{|c|c|c|c|c|c|}
\hline \multirow[b]{2}{*}{ Group } & \multirow[b]{2}{*}{$\begin{array}{l}\text { Weight } \\
\text { (g.) }\end{array}$} & \multicolumn{2}{|c|}{ Spleen } & \multicolumn{2}{|c|}{ Liver } \\
\hline & & $\begin{array}{l}\text { RNA/mg. } \\
\quad(\mu \mathrm{g} .)\end{array}$ & $\begin{array}{c}\text { Protein/mg. } \\
(\mu \mathrm{g} .)\end{array}$ & $\begin{array}{l}\text { RNA/mg. } \\
(\mu \mathrm{g} .)\end{array}$ & $\begin{array}{c}\text { Protein/mg } \\
(\mu \mathrm{g} .)\end{array}$ \\
\hline $\begin{array}{l}\text { ntrol } \\
\text { deficient* } \\
\text { deficient }\end{array}$ & $\begin{array}{l}89 \pm 7 \\
83 \pm 4 \\
79 \pm 6\end{array}$ & $\begin{array}{l}7 \cdot 5 \pm 0 \cdot 8 \\
7 \cdot 0 \pm 0 \cdot 9 \\
6 \cdot 9 \pm 1 \cdot 0\end{array}$ & $\begin{array}{l}189 \pm 11 \\
181 \pm 13 \\
179 \pm 9\end{array}$ & $\begin{array}{r}9 \cdot 9 \pm 0 \cdot 8 \\
10 \cdot 1 \pm 1 \cdot 0 \\
9 \cdot 8 \pm 1 \cdot 1\end{array}$ & $\begin{array}{l}191 \pm 13 \\
184 \pm 11 \\
185 \pm 11\end{array}$ \\
\hline
\end{tabular}

* Animals received $5 \mathrm{mg}$. of pyridoxine intraperitoneally $24 \mathrm{hr}$. before being killed. 


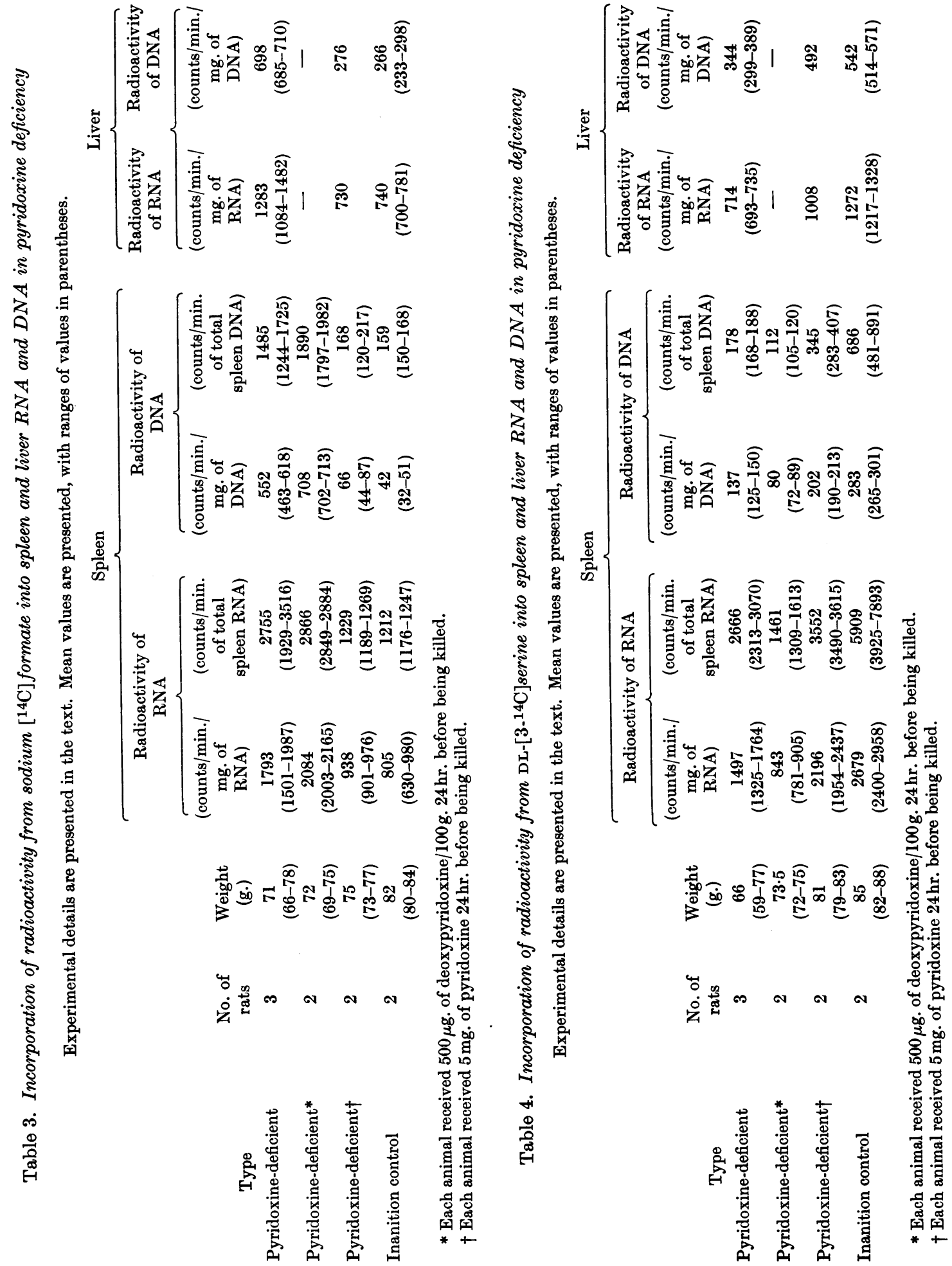


Table 5. Incorporation of radioactivity from $\left[8-{ }^{14} \mathrm{C}\right]$ adenine into spleen $R N A$ and $D N A$ in pyridoxine deficiency

Experimental details are presented in the text. Mean values are presented, with ranges of values in parentheses.

\begin{tabular}{|c|c|c|c|c|c|c|}
\hline \multirow[b]{2}{*}{ Type } & \multirow[b]{2}{*}{$\begin{array}{l}\text { No. of } \\
\text { rats }\end{array}$} & \multirow[b]{2}{*}{$\begin{array}{l}\text { Weight } \\
\text { (g.) }\end{array}$} & \multicolumn{2}{|c|}{ Radioactivity of RNA } & \multicolumn{2}{|c|}{ Radioactivity of DNA } \\
\hline & & & $\begin{array}{l}\text { (counts/min./ } \\
\text { mg. of RNA) }\end{array}$ & $\begin{array}{l}\text { (counts/min. } \\
\text { of total } \\
\text { spleen RNA) }\end{array}$ & $\begin{array}{l}\text { (counts/min./ } \\
\text { mg. of DNA) }\end{array}$ & $\begin{array}{c}\text { (counts/min. } \\
\text { of total } \\
\text { spleen DNA) }\end{array}$ \\
\hline Pyridoxine-deficient & 4 & $\begin{array}{c}80 \\
(71-90)\end{array}$ & $\begin{array}{c}1105 \\
(1054-1172)\end{array}$ & $\begin{array}{c}2220 \\
(2097-2404)\end{array}$ & $\begin{array}{c}78 \\
(36-110)\end{array}$ & $\begin{array}{c}179 \\
(121-222)\end{array}$ \\
\hline Pyridoxine-deficient* & 2 & $\begin{array}{c}80 \\
(76-84)\end{array}$ & $\begin{array}{c}1938 \\
(1893-1984)\end{array}$ & $\begin{array}{c}3168 \\
(3106-3229)\end{array}$ & $\begin{array}{c}377 \\
(373-381)\end{array}$ & $\begin{array}{c}738 \\
(715-760)\end{array}$ \\
\hline Inanition control & 2 & $\begin{array}{c}91 \\
(82-97)\end{array}$ & $\begin{array}{c}1950 \\
(1879-2036)\end{array}$ & $\begin{array}{c}4515 \\
(4217-4973)\end{array}$ & $\begin{array}{c}261 \\
(214-291)\end{array}$ & $\begin{array}{c}555 \\
(478-602)\end{array}$ \\
\hline
\end{tabular}

* Each animal received $5 \mathrm{mg}$. of pyridoxine $24 \mathrm{hr}$. before being killed.

Table 6. Incorporation of radioactivity from $\left[M e \cdot{ }^{3} \mathrm{H}\right]$ thymidine into spleen and liver $D N A$ in pyridoxine deficiency

Experimental details are presented in the text. Mean values are presented, with ranges of values in parentheses. Animals were killed $24 \mathrm{hr}$. after injection of $\left[\mathrm{Me}^{-3} \mathrm{H}\right]$ thymidine unless indicated otherwise.

\begin{tabular}{|c|c|c|c|c|c|c|}
\hline \multirow[b]{2}{*}{ Type } & \multirow[b]{2}{*}{$\begin{array}{l}\text { No. of } \\
\text { rats }\end{array}$} & \multirow[b]{2}{*}{$\begin{array}{l}\text { Weight } \\
\text { (g.) }\end{array}$} & \multicolumn{2}{|c|}{ Radioactivity of spleen DNA } & \multicolumn{2}{|c|}{ Radioactivity of liver DNA } \\
\hline & & & $\begin{array}{l}\text { (counts/min./ } \\
\text { mg. of DNA) }\end{array}$ & $\begin{array}{l}\text { (counts/min. } \\
\text { of total } \\
\text { spleen DNA) }\end{array}$ & $\begin{array}{l}\text { (counts/min./ } \\
\mathrm{mg} . \text { of DNA) }\end{array}$ & $\begin{array}{c}\text { (counts/min. } \\
\text { of total } \\
\text { liver DNA) }\end{array}$ \\
\hline Pyridoxine-deficient & 4 & $\begin{array}{c}83 \\
(68-94)\end{array}$ & $\begin{array}{c}331 \\
(92-420)\end{array}$ & $\begin{array}{c}6238 \\
(3980-8100)\end{array}$ & $\begin{array}{c}112 \\
(92-135)\end{array}$ & $\begin{array}{c}827 \\
(692-937)\end{array}$ \\
\hline Pyridoxine-deficient* & 2 & $\begin{array}{c}80 \\
(86-90)\end{array}$ & $\begin{array}{c}436 \\
(382-490)\end{array}$ & $\begin{array}{c}7152 \\
(4950-9355)\end{array}$ & $\begin{array}{c}101 \\
(100-102)\end{array}$ & $\begin{array}{c}782 \\
(762-803)\end{array}$ \\
\hline Inanition control & 4 & $\begin{array}{c}111 \\
(102-123)\end{array}$ & $\begin{array}{c}992 \\
(865-1205)\end{array}$ & $\begin{array}{c}19188 \\
(16423-22113)\end{array}$ & $\begin{array}{c}660 \\
(450-853)\end{array}$ & $\begin{array}{c}6600 \\
(4795-8003)\end{array}$ \\
\hline Inanition control* & 2 & $\begin{array}{c}122 \\
(103-142)\end{array}$ & $\begin{array}{c}1010 \\
(913-1107)\end{array}$ & $\begin{array}{c}19555 \\
(17990-21120)\end{array}$ & $\begin{array}{c}728 \\
(437-1020)\end{array}$ & $\begin{array}{c}8385 \\
(6035-10735)\end{array}$ \\
\hline
\end{tabular}

* Animals killed $66 \mathrm{hr}$. after the injection of $\left[M e{ }^{3} \mathrm{H}\right]$ thymidine.

Table 7. Incorporation of radioactivity from $[2-14 \mathrm{C}]$ deoxyuridine into spleen and liver $D N A$ in pyridoxine deficiency

Experimental details are presented in the text. Mean values are presented, with ranges of values in parentheses.

$\begin{array}{lcccccc}\text { Type } & \begin{array}{c}\text { No. of } \\ \text { rats }\end{array} & \begin{array}{c}\text { Weight } \\ \text { (g.) }\end{array} & \begin{array}{c}\text { (counts/min./ } \\ \text { mg. of DNA) }\end{array} & \begin{array}{c}\text { (counts/min. } \\ \text { of total } \\ \text { spleen DNA) }\end{array} & \begin{array}{c}\text { (counts/min./ of DNA) } \\ \text { mg. of }\end{array} & \begin{array}{c}\text { (counts/min. } \\ \text { of total }\end{array} \\ \text { liver DNA) }\end{array}$

\section{RESULTS}

The results presented in Table 1 demonstrate a decrease in number of cells/mg. of spleen tissue in pyridoxine-deficient rats. As evaluated by the $t$ test, a significant decrease in the DNA concentra- tion/mg. of this tissue was also apparent in this deficiency. Variations in bothpara meters were reflected in the constancy of the DNA concentration/nucleus. Administration of pyridoxine to deficient animals $24 \mathrm{hr}$. before they were killed effected an increase in number of cells with a 


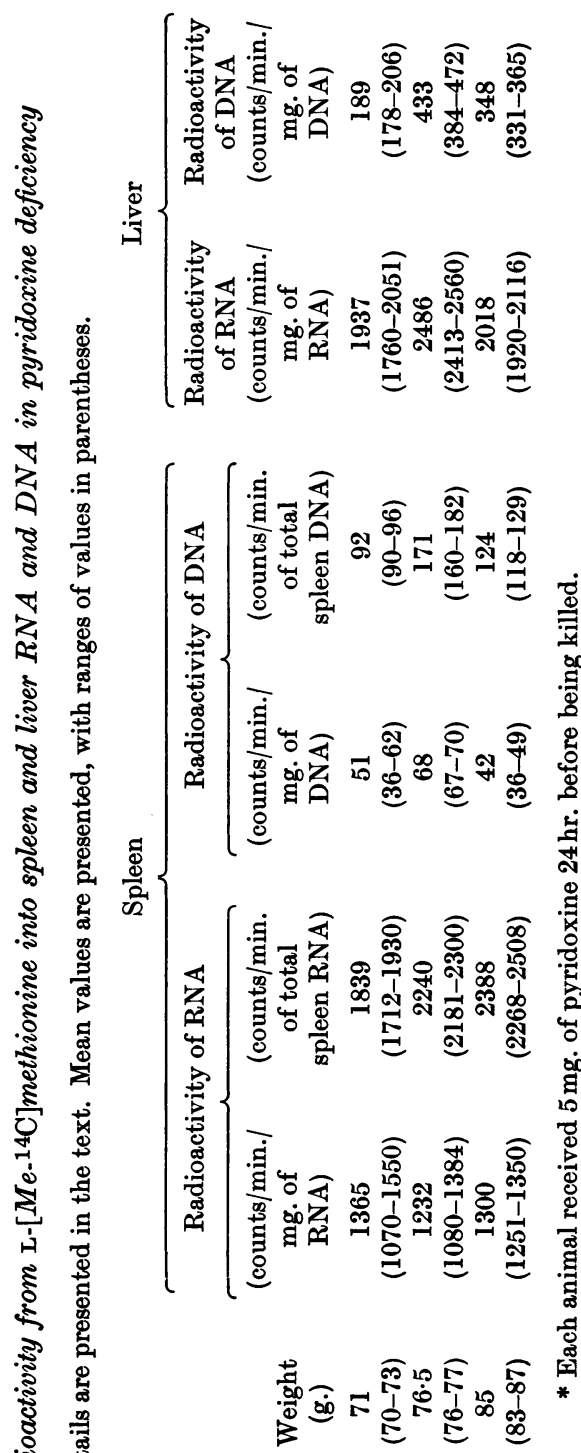

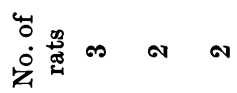

corresponding increase in DNA concentration/mg. of spleen. In contrast, neither the number of cells nor the DNA concentration/mg. of liver tissue was affected in pyridoxine deficiency. No significant effects of pyridoxine deficiency on RNA or protein concentrations of liver or spleen were observed (Table 2). In these studies, values were based on the wet weight of tissues. This basis is a valid one since repeated analyses in our Laboratory have failed to demonstrate an effect of pyridoxine deficiency on the state of hydration of these tissues.

Incorporation studies with $\left[{ }^{14} \mathrm{C}\right]$ formate yielded the finding of an apparent increased incorporation of radioactivity from this precursor compound into DNA and RNA of both liver and spleen in pyridoxine-deficient animals (Table 3). The effect on incorporation into spleen DNA was most pronounced. Administration of pyridoxine 1 day before the rats were killed was again capable of reversing these changes.

In direct contrast, pyridoxine deficiency resulted in a decreased incorporation of radioactivity from DL- $\left[3-{ }^{14} \mathrm{C}\right]$ serine into spleen and liver DNA and RNA (Table 4), from [8-14C]adenine into spleen DNA and RNA (Table 5), and from $\left[\mathrm{Me}^{-3} \mathrm{H}\right]$ thymidine and $\left[2 .{ }^{14} \mathrm{C}\right]$ deoxyuridine into spleen and liver DNA (Tables 6 and 7). There was an added effect of deoxypyridoxine on the decreased incorporation of radioactivity from $\mathrm{DL}-\left[3-{ }^{14} \mathrm{C}\right]$ serine into spleen DNA and RNA (Table 4), and the prior administration of pyridoxine reversed the changes in incorporation of radioactivity from $\mathrm{DL}-\left[3-{ }^{14} \mathrm{C}\right]$ serine and [8-14 C]adenine (Tables 4 and 5).

Pyridoxine deficiency produced no changes in the incorporation of radioactivity from $\mathrm{L}-\left[\mathrm{Me}^{-14} \mathrm{C}\right]$ methionine into spleen RNA and DNA and liver RNA and only a slight decrease of incorporation into liver DNA (Table 8).

\section{DISCUSSION}

Many of the phenomena recorded in the present paper may be linked to the role of pyridoxal phosphate in the production of $\mathrm{C}_{1}$ units via the serinehydroxymethylase reaction. Pyridoxine deficiency might then be expected to effect a decrease in available $C_{1}$ units, with a resultant decrease in the synthesis of purine and pyrimidine bases required for the production of nucleic acids. The decreased incorporation of radioactivity from $\mathrm{DL}-\left[3-{ }^{14} \mathrm{C}\right]$ serine could be explained on this basis, whereas that from $\left[8-{ }^{14} \mathrm{C}\right]$ adenine and $\left[\mathrm{Me}^{3} \mathrm{H}\right]$ thymidine might reflect the lowered rate of nucleic acid synthesis. The decreased incorporation of radioactivity from $\left[2-{ }^{14} \mathrm{C}\right]$ deoxyuridine may be related to the requirement of 'active formaldehyde' for the synthesis of thymidylic acid from deoxyuridine 5 '-phosphate. The increased specific activity of nucleic acids 
after the administration of $\left[{ }^{14} \mathrm{C}\right]$ formate to pyridoxine-deficient animals as compared with that of normal animals would reflect a greater concentration of labelled intermediate within the smaller $\mathrm{C}_{1}$ pool. Further, an interference with conversion of formate into serine would enhance the availability of formate for incorporation purposes.

No effect of the deficiency state on the incorporation of radioactivity from $\mathrm{L}-\left[\mathrm{Me}-{ }^{14} \mathrm{C}\right]$ methionine into RNA would be expected. The biosynthesis of methylated derivatives of RNA, e.g. 2-methyladenine, 6- $\mathrm{N}$-methyladenine, 6-dimethylaminopurine, methylated derivatives of guanine and 5methylcytosine, involves transmethylation with $S$-adenosylmethionine, and pyridoxal phosphate has not been implicated in this process (Greenberg, 1963). Incorporation of radioactivity from L$\left[M e-{ }^{14} \mathrm{C}\right]$ methionine into DNA is limited, since the biosynthesis of thymidylic acid involves the participation of 'active formaldehyde'.

The decreased capacity of pyridoxine-deficient animals for the biosynthesis of DNA with the subsequent deleterious effect on cell multiplication could well explain the adverse effects of this deficiency on immune responses (Axelrod \& Pruzansky, 1955; Axelrod, Trakatellis, Bloch \& Stinebring, 1963; Trakatellis, Stinebring \& Axelrod, 1963), as well as on phenomena, discussed in the introduction, that also demand an accelerated cellular growth.

The incorporation of valine into tissue protein in vivo is decreased in pyridoxine deficiency (Trakatellis \& Axelrod, 1964). The present results suggest the possibility that this effect may result from a decreased production of the necessary messenger RNA in this deficiency state.

The authors thank Mrs L. Poppe for excellent technical assistance. This work was supported by U.S. Public Health Service Research Grant A-727 from the National Institute of Arthritis and Metabolic Diseases, and by the Office of Naval Research under Contract 1833(00), NR101-412.

\section{REFERENCES}

Axelrod, A. E. \& Pruzansky, J. (1955). Vitam. \& Horm. 13, 1.

Axelrod, A. E., Trakatellis, A. C., Bloch, H. \& Stinebring, W. R. (1963). J. Nutr. 79, 161.

Bischoff, F., Ingraham, L. P. \& Rupp, J. J. (1943). Arch. Path. 35, 713.

Bosse, M. D. \& Axelrod, A. E. (1948). Proc. Soc. exp. Biol., N.Y., 67, 418.

Buchanan, J. M. (1960). In The Nucleic Acids, vol. 3, p. 303. Ed. by Chargaff, E. \& Davidson, J. N. New York: Academic Press Inc.

Burton, K. (1956). Biochem. J. 62, 315.

Crosbie, G. W. (1960). In The Nucleic Acids, vol. 3, p. 323. Ed. by Chargaff, E. \& Davidson, J. N. New York: Academic Press Inc.

Fischer, R. F., Holbrook, D. J., jun. \& Irvin, J. L. (1963). J. Cell Biol. 17, 231.

Greenberg, D. M. (1961). In Metabolic Pathways, 2nd ed., vol. 2, p. 177. Ed. by Greenberg, D. M. New York: Academic Press Inc.

Greenberg, D. M. (1963). Advanc. Enzymol. 25, 395.

Leftwich, W. B. \& Mirick, G. S. (1949). J. exp. Med.89, 155.

Littman, M. L., Taguchi, T. \& Shimizu, Y. (1963). Proc. Soc. exp. Biol., N.Y., 113, 667.

Lowry, O. H., Rosebrough, N. J., Farr, A. L. \& Randall, R. J. (1951). J. biol. Chem. 193, 265.

Miller, E. C., Baumann, C. A. \& Rusch, H. P. (1945). Cancer Res. 5, 713.

Schneider, W. C. (1957). In Methods in Enzymology, vol. 3, p.680. Ed. by Colowick, S. P. \& Kaplan, N. O. New York: Academic Press Inc.

Trakatellis, A. C. \& Axelrod, A. E. (1964). J. Nutr. 82, 483.

Trakatellis, A. C., Axelrod, A. E. \& Montjar, M. (1964). Fed. Proc. 23, 137.

Trakatellis, A. C., Axelrod, A. E., Montjar, M. \& Lamy, F. (1964). Nature, Lond., $202,154$.

Trakatellis, A. C., Stinebring, W. R. \& Axelrod, A. E. (1963). J. Immunol. 91, 39.

Weir, D. R. \& Mueller, J. F. (1951). J. clin. Invest. 30, 681. 